\title{
TKO SE BOJI VUKA JOŠ? SOCIO-EKONOMSKI I KULTURNI UČINCI OBITAVANJA VUKA U HRVATSKOJ ${ }^{1}$
}

\section{Sanja Tišma, Daniela Angelina Jelinčić, Iva Tolić, Andrea Solić i Snježana Malić}

Limari

\author{
Institut za razvoj i međunarodne odnose \\ Ulica Ljudevita Farkaša Vukotinovića, 2, 10000 Zagreb \\ e-mail:sanja.tisma@irmo.hr
}

\section{Sažetak}

Očuvanje vukova u modernim europskim krajolicima pokazalo se vrlo zahtjevnim procesom zbog niza izazova povezanih s njihovom prisutnošću $i$ kontroverzom u vezi s načinom na koji bi se njima trebalo upravljati. Republika Hrvatska danas je jedno od rijetkih područja obitavanja vukova u Europi.

$U$ članku je prikazana analiza recentnih znanstvenih istraživanja o socio-ekonomskim $i$ kulturnim učincima vuka na lokalne zajednice u kojima obitava. Osim analize relevantnih znanstvenih istraživanja o vuku, članak donosi rezultate prvog istraživanja socio-ekonomskog $i$ kulturnog utjecaja vukova u Hrvatskoj. Istraživanje je provedeno u razdoblju od srpnja do listopada 2019. u lokalnim zajednicama u kojima su vukovi tradicionalno prisutni. Hipoteza je istraživanja da kvalitetne informacije o populaciji vukova pružaju više mogućnosti za njihovo praćenje, prihvaćanje i upravljanje njima u lokalnim zajednicama. Rezultati dobiveni provedenim istraživanjem ukazuju na potrebu dodatne edukacije i snažne mecusektorske prekogranične suradnje radi boljeg razumijevanja dinamike populacije vukova $i$ njihovog utjecaja na održivi lokalni razvoj i zajedničko očuvanje prirodne i kulturne baštine.

Ključne riječi: obitavanje vuka, socio-ekonomski učinci, kulturološki učinci, lokalno stanovništvo, turizam, brendiranje

\section{UVOD}

Doprinosi ekosustava ono je što prirodni okoliš direktno i indirektno daruje ljudima. Ekosustav pruža socio-ekonomske koristi društvu i lokalnim zajednicama, posebice u vezi s kvalitetom života ljudi u njihovom neposrednom okruženju. Iako ono što nam ekosustav omogućuje danas bilježi sve veći značaj u upravljanju okolišem i prirodom, kulturni učinci

1 Istraživanje je provedeno uz podršku WWF Adria, Zagreb kroz projekt LIFE EuroLargeCarnivores i Sveučilišta u Ljubljani kroz projekt INTERREG Carnivora Dinarica 
poput duhovnih vrijednosti, kulturnih vrijednosti prirodne baštine te psihološkog dobrog stanja ljudi nisu dovoljno istraženi. Kulturne prednosti ekosustava omogućavaju ostvarivanje nematerijalnih koristi za društvo i često pozitivno utječu na očuvanje i zaštitu prirode. Upravo se kod kulturnih doprinosa ekosustava velikih zvijeri tj. vuka, medvjeda i risa, u posljednje vrijeme primjećuje najviše promjena. U prošlosti su koristi od tih divljih životinja ostvarivali uglavnom lovci (lov, trofeji), a danas se ostvaruje dobrobit za cijelo društvo jer se velike zvijeri sve više koriste kao simbol očuvane prirode. Time su vuk, medvjed i ris dobili novu ulogu u najrazličitijim područjima ljudskog djelovanja, posebno u zaštiti prirode, obrazovanju, znanstvenim istraživanjima, rekreaciji, turizmu, prepoznatljivosti područja, promociji i brendiranju lokalnih zajednica.

\section{SOCIO-EKONOMSKI I KULTURNI UČINCI VELIKIH ZVIJERI}

Upravljanje velikim zvijerima u koje se ubraja i vuk, podrazumijeva niz kontinuiranih aktivnosti koje zahtijevaju znatna financijska ulaganja. Primjerice, to su tehničke mjere zaštite domaćih životinja u područjima u kojima obitava vuk, logistika za praćenje veličine i distribucije populacije, provođenje ekoloških i genetskih istraživanja, plaćanja naknade za štete koje je vuk uzrokovao ili financiranje razvoja mjera za ublažavanje sukoba, nastojanja i htijenja za održanje staništa velikih zvijeri (Linnell i sur., 2018). Vukovi se posljednjih desetljeća vraćaju u područja u kojima generacijama nisu živjeli. Tu nailaze na slabo čuvane domaće životinje, što često dovodi do predacije i znatnih ekonomskih gubitaka. Posljedično, vlade ulažu znatna sredstva za prevencije i naknade štete, kao i za osiguravanje područja u kojima su populacije vukova strogo regulirane. U Baskiji na sjeveru Španjolske za izravne naknade i sprječavanje napada vukova u razdoblju od 2003. do 2004. uloženo je 108.696 eura, od čega je oko 60\% sredstava uloženo u preventivne aktivnosti, uključujući dodjelu i edukaciju pasa čuvara za potrebe lokalnog stanovništva (Echegaray i Vila, 2010). U Kirgistanu, gdje je stočarstvo jedna od glavnih gospodarskih aktivnosti, vukove doživljavaju kao prijetnju budućem ekonomskom razvoju zemlje (Lescureux i Linnell, 2013).

Isplate naknada za gubitke stoke uslijed predacije uobičajene su tehnike zaštite stočara od ekonomskih gubitaka. Naknadu plaćaju različite agencije, vlade i ministarstva, nevladine organizacije ili se sredstva osiguravaju kroz različite sheme poljoprivrednog osiguranja (Linnell i Cretois, 2018). Za štete od medvjeda i vuka u Francuskoj, Grčkoj, Italiji, Austriji, Španjolskoj i Portugalu prosječno se izdvaja oko 2 milijuna eura godišnje, dok je 2,15 milijuna eura utrošeno za preventivne mjere (Navarro i Pereira, 2015). U Švedskoj su ovce vrsta koju vukovi najčešće napadaju, a za nastale štete u 2013. lokalnom je stanovništvu isplaćeno oko 0,25 milijuna eura (Widman i Elofsson, 2018). U Hrvatskoj su u 2014. zaprimljena 1.474 zahtjeva za naknadu štete od predatora, od čega je u $96 \%$ slučajeva (1.419 zahtjeva) štetu sigurno ili vrlo vjerojatno počinio vuk (Jeremić i Štrbenac, 2014). U razdoblju od 2014. do 2019. ukupna vrijednost odšteta isplaćenih lokalnom stanovništvu u vezi s aktivnostima velikih zvijeri iznosila je 9.162.741,80 kuna (Jeremić i Štrbenac, 2015). 
Štete na usjevima i drveću nadilaze štete nanesene domaćim životinjama. Regija Asturija jedino je područje u Španjolskoj u kojem lokalna uprava nadoknađuje stanovništvu tu vrstu šteta od medvjeda i vukova u prosječnim godišnjim iznosima od oko 127 tisuća eura (Fernandez-Gil i sur., 2016). Štete na usjevima i voćnjacima nastale od velikih zvijeri česte su i u Turskoj. Istraživanje provedeno u okrugu Yusufeli na jugoistoku Artvina pokazalo je kako je tijekom 2003. i 2004. 51\% stanovnika pretrpjelo štetu od velikih zvijeri (Ambarly i Bilgin, 2008).

Prate se i posredni troškovi napada velikih zvijeri poput vremena provedenog na podnošenju zahtjeva za naknadu štete, smanjenja vrijednosti zemljišta zbog napada velikih zvijeri, administrativnih troškova provjere događaja koju provode rendžeri i sl. (Fernandez-Gil i sur., 2016). Istraživanje provedeno u Danskoj pokazuje kako stanovnici Jutlanda vuka smatraju nepoželjnim, ne samo zbog štete počinjene na domaćim životinjama nego dijelom i uslijed gubitka vremena provedenog u potrazi za nadoknadom te vremena utrošenog na provedbu mjera za koje nisu planirane nadoknade poput izgradnje i održavanja zaštitnih ograda i sl. (Højberg i sur., 2017).

Prisutnost vuka smanjuje atraktivnost područja za lov, što dovodi do smanjenja prihoda od lovnog turizma. Protivnici povratka risova i vukova na području Europe i Sjeverne Amerike uglavnom su lovci na jelene. Na Aljasci lovci smatraju da je povećanje populacije vukova uzrok smanjenja populacije losa te smanjenja lovnih kvota (Sillero-Zubiri i Laurenson, 2001).

Uz niz potencijalnih troškova koje vuk uzrokuje u lokalnim zajednicama u kojima obitava, sve značajnije su koristi dodatnog potencijala za razvoj turizma. Primjerice, ponovno nastanjivanje vukova u nacionalnom parku Yellowstone u Sjedinjenim Američkim Državama privuklo je nove turiste, generirajući ekonomske i društvene koristi procijenjene na 6 do 9 milijuna američkih dolara godišnje (Cerqueira i sur., 2015). Ponovno naseljavanje vukova u Nacionalni park Yellowstone također je dovelo do smanjenja populacije losova (lat. Alces alces) te do oporavka raznih biljnih vrsta, porasta šumskog raslinja i porasta turističke atraktivnosti područja nacionalnog parka (Ripple i Beschta, 2004).

Obitavanje vuka i ostalih velikih zvijeri kao potencijal za razvoj ekoturizma zahtijeva jasno definiranje mjera koje će osigurati minimalni utjecaj posjetitelja na populaciju velikih zvijeri u njihovom prirodnom okruženju (Palazón, 2017).

Osim razvoja turizma i očuvanja bioraznolikosti, vukovi i ostale velike zvijeri pridonose ostvarivanju ekonomske koristi uporabom njihova lika u marketinške svrhe, primjerice u promociji usluga i odredišta turizma i markiranja regionalnih poljoprivrednih proizvoda, odjeće i opreme. Primjerice, švicarska regija St Bernard naljepnice vuka koristi za promidžbu regije (Boitani, 2000).

Stavovi i mišljenja ljudi o vuku i velikim zvijerima znatno se razlikuju što često dovodi do sukobljenih prioriteta i ciljeva koji se odnose na upravljanje. Globalno podržavaju se politike kojima se promiče očuvanje biološke raznolikosti i posljedično obitavanje vuka i velikih zvijeri u njihovim povijesnim lokalitetima. Ipak, lokalne zajednice ponekad ove zvijeri smatraju prijetnjom za život i sigurnost ljudi. Negativne emocije poput stresa, straha ili bijesa i s tim u vezi smanjenje aktivnosti na otvorenom podrazumijevaju nema- 
terijalni utjecaj vuka i velikih zvijeri na ljude. Razina društvenog sukoba koja proizlazi iz napora za očuvanjem vrsta poput vukova i medvjeda može u nekim područjima biti intenzivna, posebno u staništima u koja se vukovi vraćaju nakon dužeg perioda (Boitani i Linnell, 2015).

Obitavanje vuka u lokalnim zajednicama ima određene zdravstvene učinke. Vukovi se često hrane bolesnim životinjama čime smanjuju mogućnost zaraze unutar populacije, ali i neizravno smanjuju utjecaj bolesti na pripitomljene vrste. Primjerice, održavanje populacije vukova u Kanadi znanstvenici smatraju načinom za smanjenje prijenosa tuberkuloze goveda (uzročnik lat. Mycobacterium bovis) s divljih kopitara na domaće životinje (Klinkhart i sur., 2018).

Rezultati istraživanja provedenog u Poljskoj ukazuju na otvorenost lokalnog stanovništva za suživot $s$ vukovima i ostalim velikim zvijerima, sve dok to ne predstavlja prijetnju za sigurnost ljudi u njihovu neposrednu okruženju (Rode i sur., 2019). Slične nalaze sadrži i istraživanje o velikim zvijerima provedeno u Litvi u kojem više od 80\% ispitanika smatra da bi bilo vrlo uzbudljivo vidjeti medvjeda ili vuka u šumi (Balčiauskas i Kazlauskas, 2012). U Norveškoj 73,6\% sudionika smatra da zvijeri trebaju obitavati u toj zemlji (Røskaft i sur., 2007). Većina Šveđana smatra da bi u Švedskoj trebali obitavati vukovi, (Ericsson i Heberlein, 2003). U Portugalu je nešto lošija percepcija vukova koji se danas nalaze na oko $20 \%$ prvotnog područja njihova obitavanja čemu je uzrok progon zbog šteta počinjenih na stoci (Milheiras i Hodge, 2011).

Stavovi šire javnosti o prisutnosti vuka u lokalnim zajednicama obuhvaćaju raspon od izrazito pozitivnih do izrazito negativnih. Stanovništvo u ruralnim područjima Škotske posebno je osjetljivo na pitanje ponovnog uvođenja vukova (Nilsen i sur., 2007) koji tamo ne borave već tri stoljeća. Vuk se u javnosti često povezuje s lokalnom poviješću, kulturom i običajima, kroz različite priče i legende, filmove, obrede i proslave, brendiranje lokalnih zajednica, proizvoda i usluga. Također, vuk simbolizira hrabrost, inteligenciju, brzinu i otpornost (Rode i sur., 2019). U tradiciji južnih Slavena i nekih drugih indoeuropskih naroda vuk predstavlja demonsku životinju. Hrvatska je jedna od rijetkih europskih zemalja u kojima obitava vuk, što između ostalog, ukazuje, na očuvanu i raznoliku prirodnu baštinu. $S$ vukom su povezani različiti obredi i običaji. U prošlosti, kad su se ljudi bavili stočarstvom, vukovi su lokalnom stanovništvu nanosili znatnu štetu. Ako se pojavio vuk, lovci bi ga ubili, oderali mu kožu i ispunili je slamom. Potom bi s vukom išli od kuće do kuće pucajući iz puške u zrak i pjevajući, a seljani bi im davali novac i hranu. Zbog tih je običaja u šibenskom zaleđu ostalo mnogo narodnih pjesama vezanih za vukove (Dragić, 2010). Istraživanja o stavovima stanovnika prema prisutnosti vukova u Hrvatskoj provedeno je u nekoliko navrata.

Prva istraživanja o vuku u Hrvatskoj sežu u 1983., a ponovljena su 1987. i 1993. Prve analize pokazuju da se $42 \%$ ispitanika bojalo vuka i nije ga željelo u sredini u kojoj živi, a deset godina kasnije takav je stav iskazalo $25 \%$ stanovnika (Huber i sur., 1994). Nekoliko godina kasnije provedeno je novo istraživanje koje je uključivalo dva ispitivanja kojima su se prikupljali stavovi lokalnog stanovništva o vukovima u Gorskom kotaru i Dalmaciji, te su, također, zabilježeni pozitivni pomaci prema intenzivnijem prihvaćanju 
obitavanja vukova u lokalnim zajednicama (Majić i Bath, 2009).

Unatrag tridesetak godina provedeno je niz istraživanja o velikim zvijerima uglavnom u području prirodnih znanosti, a unatrag desetak godina intenziviraju se istraživanja kako u društvenim tako i u humanističkim znanostima (Linnell, 2013). Rasprave o regionalnom i lokalnom razvoju i identitetu te postizanje konsenzusa o temi obitavanja vuka u lokalnim zajednicama prigoda su za komunikaciju različitih zainteresiranih skupina. Također, planiranje očuvanja populacije vuka u Europi prilika je za intenziviranje prekogranične suradnje, razmjenu znanja i iskustava te dobrih praksi u upravljanju vukom. Pozitivni učinci prekogranične suradnje su u redovitoj komunikaciji među stručnjacima, mogućnostima za razmjenu podataka, iskustava i tehnika za terenski rad te samim time u učinkovitijem korištenju resursa za istraživanje i praćenje vuka (Blanco, 2012).

\section{METODOLOGIJA ISTRAŽIVANJA}

Kulturni učinci ekosustava definiraju se kao nematerijalne dobrobiti za ljude kroz duhovno oplemenjivanje, kognitivni razvoj, promišljanje, rekreaciju i estetska iskustva. Mogu biti estetski, duhovni, obrazovni i rekreacijski, a uključuju kulturnu raznolikost, duhovne i religijske vrijednosti, znanje (tradicijsko i formalno), obrazovne vrijednosti, inspiraciju, estetske vrijednosti, društvene odnose, vrijednost mjesta, vrijednost kulturne baštine, rekreaciju i turizam, perspektivu / pogled, povezanost s prirodom te društvene veze.

Kulturni učinci obitavanja vuka u lokalnoj zajednici u Hrvatskoj do sada nisu istraživani. Stoga je tijekom rujna i listopada 2019. na području Republike Hrvatske provedeno istraživanje o kulturnim učincima prisutnosti vuka u lokalnim zajednicama.

U istraživanju je sudjelovalo 29 sugovornika s područja Like, Gorskog kotara, Dalmacije i Žumberka. Sudionici su bili različite dobi (od 27 do 83 godine), različitih zanimanja i različite razine obrazovanja, a većina ispitanika pripadala je dobnoj skupini od 40-50 godina starosti. $U$ istraživanju su sudjelovala i tri turista koji su se zatekli u tom području i uživali u prirodnim ljepotama, tišini i odmoru od gradske gužve.

Istraživanje je provedeno u obliku polustrukturiranih intervjua u trajanju od 30 do 45 minuta. Upitnik se sastojao od 46 pitanja, podijeljenih u 12 dijelova, a odgovorima na ta pitanja dobiveni su kvalitativni i kvantitativni podaci. Nakon uvodnog dijela koji je od ispitanika tražio asocijacije na vuka i aktivnosti povezane s vukom, slijedio je dio o osobnim iskustvima koja se odnose na vuka. Treći i četvrti dio upitnika sastojao se od pitanja povezanih $s$ koristima i nedostacima koje za ljude ima postojanja vukova na tom području, dok je peti dio povezan s turizmom i rekreacijom. Podaci prikupljeni pitanjima iz šestog dijela upitnika služili su za analizu duhovne vrijednosti vukova. Sedmi dio upitnika odnosio se na umjetničku vrijednost, a osmi na prirodnu i kulturnu baštinu. Lokalno tradicionalno znanje analizirano je pomoću odgovora iz devetog dijela, dok se deseti odnosio na proslave i obrede povezane s vukovima. Jedanaesti dio upitnika odnosio se na procjenu obrazovne vrijednost vukova, a posljednji, dvanaesti dio na međunarodne vrijednosti. 


\section{REZULTATI ISTRAŽIVANJA}

Osobna iskustva povezana s vukom imalo je 23 od 29 sudionika ispitivanja (79,3\%). Jedan od sugovornika ispričao je kako je u razdoblju 1960.-1970. godine na području okolice Otočca uobičajen prizor bio vidjeti vukove tijekom zimskih noći, posebice ako je bilo snijega. Sudionica ispitivanja koja radi na projektu vezanom za velike zvijeri sudjelovala je na rezidbi vuka, tj. monitoringu pomoću zavijanja u Sloveniji. Značajnija iskustva sa vukom naveli su lovci i stočari. Jedan lovac je vidio tri vuka kako jedu otpadnu hranu iz klaonice koju su lovci ostavili kao mamac za medvjede. Kad su čuli buku, vukovi su pobjegli. Drugi lovac imao je iskustva s dva vuka koji su mu presjekli put u blizini lovačke kućice. Dugo su stajali pred njim i gledali ga, a zatim krenuli dalje. Osim osobnih iskustava, većina sugovornika poznaje nekoga tko je imao iskustva $s$ vukovima ili su o tome čuli razne priče. Najviše su to bili direktni susreti s vukom na pristojnoj udaljenosti ili situacije u kojima je vuk odnio pse ili ovce. Jedan je sugovornik ispričao iskustvo poznanika s vukovima - vozio se $s$ kolegom na posao u Nacionalni park Risnjak te je ugledao kako se na livadi na snijegu igra čopor od 5 odraslih vukova. Promatrao ih je u igri, obuzela ga je radost i uzbuđenje što je tome mogao svjedočiti i to iskustvo smatra prelijepim. Sugovornik je doživio je da mu je vuk ušao u štalu. Kaže da vuk prvo ispita teren - skoči unutra, iskoči van, onda opet uskoči i napravi „dar mar“ i izađe van. Kod susjeda je jednom prilikom tako vuk uskočio u štalu, ali nije mogao iskočiti van zbog neke prepreke. Vuk cijelu noć nije udavio niti jednu ovcu - nije htio, nego je strpljivo čekao da ujutro gazda otvori vrata, pogledali su se u oči i vuk je pokunjen izašao van - sugovornik je rekao kako osjeća „veliko strahopoštovanje za tu životinju, velika pamet, inteligencija - ne napraviti štetu jer znaš da ne možeš pobjeći i da imaš veće šanse da te gazda pusti“.

$\mathrm{Na}$ pitanje boje li se vuka, većina sugovornika (79,3\%) odgovorila je negativno, da se ne boji, a svega se 5 osoba $(17,24 \%)$ vuka boji. Jedan sugovornik nije odgovorio na ovo pitanje.

Većinu sudionika istraživanja nisu plašili vukom dok su bili djeca, a osam je sugovornika reklo da su ih plašili vukovima. Najčešće su ih plašili vukom kako ne bi izlazili zimi na hladnoću, pričali su im bajke o vukovima u kojima je vuk okrutan, govorili da će ih vuk odnijeti i pojesti, te da ne pojedu li oni ponuđeni obrok da će im ga pojesti vuk. Općenito, vuk je korišten kao prijetnja kako bi se djeca ponašala na „primjeren“ način, kako bi im se ograničio radijus kretanja te kako bi bila „dobra da ih vuk ne odnese.“

Okrutnosti povezane s vukom sudionici istraživanja interpretirali su na dva načina. Pojedince je to asociralo na vučje okrutnosti, poput nemilosrdnosti i okrutnosti vuka koji kad napada plijen ne ubije ga odmah, nego ga grize za noge te ga prvo sruši, a zatim ubije. Nekoliko je sugovornika smatralo da vuk ne ubija samo iz potrebe, nego i iz užitka. Druga interpretacija vezana je uz okrutnost ljudi prema vukovima uglavnom kroz bajke kao što su Crvenkapica, Vuk i sedam kozlića te razne basne i sl., u kojima je ponašanje ljudi i životinja prema vukovima bilo okrutno.

Od ekonomskih koristi za ljude uslijed prisustva vuka u lokalnoj zajednici, najviše sugovornika spomenulo je turizam. Zimi vuk ostavlja tragove u snijegu što pruža mogućnosti za razvijanje turizma u divljini, koji uključuje foto-safari, praćenje tragova, slušanje 
zavijanja i sl. Vuk sam po sebi predstavlja atrakciju, ljudi ga vole vidjeti i u zoološkom vrtu, a istinski zaljubljenici u prirodu bi ga sigurno voljeli vidjeti i u njegovom prirodnom staništu. Također, atraktivnost vukova predstavlja mogućnost za izradu zanimljivih suvenira, brendiranje područja ili usluga, organizaciju događanja s temom vuka te za razvoj novih obrazovnih programa. Nematerijalne koristi od vuka prvenstveno se odnose na održavanje ekološke ravnoteže.

Većina sudionika u istraživanju smatra kako bi se život promijenio ukoliko više ne bi bilo vuka na područjima na kojima obitavaju. Nekolicina sugovornika smatra kako bi se život promijenio na bolje - više ne bi bilo opasnosti od vuka za stoku i njih same, budući da više ne bi živjeli u strahu. Ipak, većina ispitanika smatra da bi se život promijenio na gore budući da bi ekološka ravnoteža bila narušena. Spominju da se vuk nalazi na vrhu hranidbenog lanca, kontrolira broj divljači i znak je biološke raznolikosti i očuvane prirode. Također, vuk je simbol područja na kojima je provedeno istraživanje, oduvijek je tamo i ljudi su naučili živjeti s njim.

Sugovornici smatraju da su pozitivni aspekti vuka koji bi se trebali intenzivnije promovirati u javnosti prvenstveno povezani njegovom ulogom u očuvanju ravnoteže ekosustava. Stoga predlažu da se organiziraju obrazovne aktivnosti i eventualno snimi dokumentarni film o važnosti velikih zvijeri za očuvanje prirode. Bitno je istaknuti što bi se dogodilo kada vuka više ne bi bilo - došlo bi do širenja bolesti kod papkara, svinjske kuge i sličnih bolesti koje utječu i na ljudsko zdravlje. Domaćem stanovništvu trebalo bi prezentirati turizam u divljini i mogućnosti koje on pruža.

Nedostaci za ljude koje nosi život u prisustvu vukova odnose se većinom na štete koje vukovi nanose stoci te na strah od vukova. Jedna sudionica istraživanja spomenula je da se strah većinom temelji na neznanju i predrasudama, da sektor zaštite prirode i lovstva nije usklađen i ne surađuje te da lovcima vuk „čini štetu“ na fondu divljači (hrani se prirodnim plijenom kojim gospodari čovjek) te moraju prilagoditi lovno gospodarenje koje je „samo po sebi hrpa (nesuvislih) papira za rješavanje“, ali se to mora činiti zbog inspekcija i kazni. Smatra da bi se to nekako trebalo promijeniti, osuvremeniti, početi bolje informirati javnost o koristima od vuka. Sugovornica je spomenula i problem krivolovaca. Uglavnom, većina sugovornika smatra da ne postoje nedostaci za ljude, da su ljudi naučili živjeti s vukovima i čuvati stoku od šteta.

Turizam i rekreacija prepoznati su kao ključne ekonomske koristi za lokalnu zajednicu zbog prisustva vuka. Sugovornici navode mogućnost intenzivnijeg razvoja turizma u divljini kroz koji bi zainteresirani turisti mogli posjetiti mjesta na kojima obitavaju velike zvijeri te promatrati njihove tragove. Prisutnost vuka smatra se prilikom za istraživanje i edukaciju ljudi (engl. citizen science, sustav volontera, edukacijske ture, interpretacijski centri). Također, obitavanje vukova na područjima istraživanja stvara priliku za njihovo brendiranje, izradu suvenira, otvaranje obrta te promoviranje biološke raznolikosti ruralnih područja Hrvatske.

Vukovi predstavljaju i duhovnu vrijednost ljudima koji žive u područjima gdje obitavaju te oni većinom ne mogu zamisliti šumu bez vuka. Na pitanje kako se osjećate kad znate da posjećujete područje / živite na području gdje sve tri velike zvijeri obitavaju 
u šumama, uključujući i vuka, svi sugovornici su iskazali izrazito pozitivne osjećaje. Najviše ih je ponosno što žive na takvom području (34,62\%), izjavili su da ta spoznaja budi osjećaj sreće (15,38\%), dok je za dvoje sudionika istraživanja to normalno stanje. Osjećaji koje su sugovornici spomenuli su: poštovanje i strahopoštovanje, pravi dojam divljine i prirode, osjećaju se kao da ulaze u njihov dom, osjećaj bogatstva i sl.

Svi sudionici istraživanja smatraju da bi vukovi trebali slobodno živjeti na teritoriju Republike Hrvatske u svojim drevnim, prirodnim staništima, na područjima Like, Gorskog kotara, Dalmacije, Korduna. Jedan sudionik istraživanja naveo je da bi vukovi trebali živjeti tamo gdje imaju dovoljno plijena i gdje ih ljudi toleriraju. Suživot se postiže edukacijom, otvorenom komunikacijom, brzom reakcijom na štetu, određenim ustupcima (npr. proizvođač stoke bi državi plaćao manji porez), pomaganjem pri sprečavanju šteta, ozbiljnim i stručnim pristupom te edukacijom medija.

Većina sudionika u istraživanju (82,76\%) smatra da je vuk sam po sebi specifična životinja koja budi različite asocijacije kod ljudi, od tajanstvenosti i strahopoštovanja do elegancije i divljine, može biti snažan izvor ideja i inspiracije za likovnu umjetnost, književnost, glazbenu i plesnu umjetnost te druge oblike kreativnosti.

Područje Like, Gorskog kotara i Dalmacije poznato je po prisutnosti vuka te on u njima predstavlja važan dio baštine i tradicije. Vuk je oduvijek tu, dio je kulturne baštine, običaja, tradicionalnih priča i narodne književnosti. Jedan sugovornik opisao je vuka kao dio žumberačke baštine povezane $s$ doseljenjem uskoka od kojih su mnogi imali ime ili prezime $s$ varijacijom imenice vuk.

Izgled vuka i njegova mističnost razlog su brojnih primjera simbolike, folklora i izreka povezanih s vukom. Primjer koji su naveli sugovornici su Zimske olimpijske igre u Sarajevu čija je maskota bio vuk Vučko. Sugovornici su spomenuli i vučarske / vukarske običaje na prostoru Like, Dalmacije i zapadne Bosne što je dobro prikazano u filmu „Vuk samotnjak“, kao i običaj oponašanja vukova na svadbama (mladi momci koji rade metež / zavijaju dok im domaćini ne daju hrane i pića) te zvončara koji tjeraju zvijeri i dozivaju proljeće.

$\mathrm{Na}$ područjima u kojima je provedeno istraživanje simbolika vuka postoji i u imenima naselja. Dvoje sugovornika je navelo da je naziv Lika došlo od grčke riječi Lykos koja znači vuk. Sugovornici navode niz naziva mjesta u Hrvatskoj koja su povezana s vukom na području istraživanja, ali i šire. Poznata je Vučja jama u NP-u Risnjak, prijelaz Vučjak, zaseok Vukovići, planina Učka (Vučka), livada Zvjerinjak, Vučja dolina, Vučedol, Vukovar, sela u Lici Vučnik, Vučkovići, Kurjak, Vukov dol na Medvednici, sela u Žumberku: Vukšići, Vukovo Brdo, Vuketići, Delivuki, lokaliteti: Vučji jarak - u Brezovici, Vučja draga, Vučipolje, Vukova draga, Vučji prolaz, Vukova Gorica.

Prisustvo vuka na područjima na kojima je provedeno istraživanje potiče održavanje nekih tradicionalnih vještina i navika poput sklanjanja i zaštite stoke noću, čuvanja stoke na ispaši, držanja lovačkih pasa i građenja torova. Sugovornici navode da je razlika u načinu života u odnosu na prošlost očigledna. U prošlosti, dok je u selima bilo više ljudi koji su se bavili poljoprivredom, obrađivali polja i bavili se stočarstvom, šuma je bila dalje od kuća te vukovi nisu dolazili blizu sela. Upravo u tome sugovornici prepo- 
znaju značaj tradicionalnog znanja koje je omogućavalo suživot ljudi i velikih zvijeri. Ekstenzivno držanje stoke omogućava održavanje staništa i krajobraza (nema zarastanja, drugačija bioraznolikost) i „etičnije“ držanje domaćih životinja (životinje su vani, pasu prirodnu hranu, meso i mlijeko je kvalitetnije).

Prisutnost vukova, smatraju sugovornici, pomogla je oblikovanju lokalnog života. S jedne strane, način života je oprezniji, ljudi ne ostavljaju hranu vani kako ne bi privukli velike zvijeri, način držanja i čuvanja stoke, kao i način gradnje prilagođava se činjenici da žive u prisustvu vukova. Danas su ljudi svjesni njihove prisutnosti i nužnosti čuvanja stoke te su znatno tolerantniji prema vuku, nego što su bili u prošlosti. Također, oni koji žive u okolici nacionalnih parkova u kojima obitavaju vukovi vide korist koju njihova prisutnost donosi privlačenjem većeg broja turista.

Na pojedinim lokacijama u Republici Hrvatskoj vukovi su bili inspiracija za proslave i obrede - poznati su primjeri zvončara, vukarski / vučarski običaji te svadbeni običaji. Uz najmlađeg sugovornika koji se sjeća priča iz djetinjstva, samo najstariji sudionici istraživanja sjećaju se razdoblja prije nego je vuk postao zaštićena vrsta i kada ga se još smjelo ubijati. Obred koji je postojao u selima u vezi $s$ vukom bio je da ga se mrtvog zaveže na kolac i nosi po selu, a ljudi daruju osobu koja ga je ubila budući da je spasila stoku. Također, u povijesti su vukovi bili dijelom svatovskog obreda. Prema priči sudionice istraživanja, srijedom po danu održavala su se vjenčanja, a tijekom prve bračne noći momci bi zavijali oko kuće dok ih ne pozovu na jelo i piće. Običaj Pesniki, koji se i danas zadržao, a i najviše je puta spomenut u ispitivanju, karneval je koji nagovještava proljeće i buđenje iz zimskog sna.

Živeći u području gdje je vuk prisutan sugovornici su naučili puno toga o suživotu čovjeka i vuka. Smatraju da je taj suživot moguć i da je prisutnost vuka važna za održavanje ekološke ravnoteže. Većina ispitanika $(72,41 \%)$ izjavila je da se u suživotu s prirodom može nešto naučiti o vukovima, odnosno da su nešto naučili. Naučili su da vuk nije opasan za ljude, da ima mjesta za sve. Jedan od sudionika istraživanja naglasio je da „treba biti tolerantan i imati razumijevanja i za probleme ljudi, ali i za potrebe vukova“.

Većina ispitanika (75\%) smatra da će njihova djeca i potomci u budućnosti nastaviti živjeti s vukovima i drugim velikim zvijerima. Pojedini ispitanici smatraju da se ništa neće promijeniti, da je odnos prema vukovima stabilan u posljednje vrijeme te da će status zaštite pomoći da se njegova populacija održi. Neki od ispitanika koji su se složili da će „vukova biti“ smatraju da je to tako zbog izrazite depopulacije njihova područja, zbog toga što mladi odlaze u inozemstvo, što je ljudi sve manje, a šume, kao prirodnog staništa velikih zvijeri, sve više. Jedna četvrtina ispitanika koji su odgovorili na ovo pitanje smatra da suživot ljudi i velikih zvijeri neće postojati u budućnosti, a jedan od njih smatra da je razlog u tome što su se ljudi previše otuđili od prirode te da je došlo do promjene načina života i odnosa prema životinjama. Neki ispitanici smatraju da će vuk izumrijeti, da je stoke i hrane u njegovim prirodnim staništima sve manje i da će djeca moći upoznati vuka samo kroz priče i legende.

Sudionici u istraživanju većinom smatraju da se odnos prema vukovima promijenio u posljednjim desetljećima, neki smatraju da se promijenio na bolje, a neki na gore. 
Ispitanici koji misle da se odnos promijenio na bolje kažu da su ljudi svjesni njihove vrijednosti, da su educiraniji, uključeniji i tolerantniji te da prihvaćaju vukove. Došlo je do pozitivne promjene stava što je posljedica zakonske regulative, statusa zaštite i strogih kazni, zatim, djelomično, isplaćivanja odšteta, a djelomično je to i rezultat sve boljeg obrazovanja stanovništva, koje je svjesno važnosti i uloge vuka u ekosustavu.

Svi sudionici u istraživanju voljeli bi da za 30 godina vuk i dalje postoji i živi na području Republike Hrvatske. Ispitanici se slažu da bi vuk trebao slobodno živjeti u svom prirodnom staništu, da bi mu populacija trebala rasti u razmjeru s kapacitetom staništa. Općenito je mišljenje da je vuk pokazatelj bioraznolikosti, da čuva ekološku ravnotežu i da bi djeca, poput nekad njihovih roditelja, trebala živjeti s njim u područjima u kojima obitava. Također, lokalno stanovništvo trebalo bi više informirati o vuku, dok bi lokalne zajednice trebale uložiti više napora u provedbu mjera koje omogućavaju suživot s vukovima.

\section{ZAKLJUČAK}

Iako u području prirodnih znanosti postoji niz istraživanja o populaciji vuka, u području društveno humanističkih znanosti tek se unatrag desetak godina intenziviraju istraživanja o pozitivnim i negativnim učincima vuka i velikih zvijeri općenito.

Većina istraživanja temelji se na prikazu i analizi ekonomskih gubitaka uslijed šteta koje vukovi nanose lokalnom stanovništvu te potencijalnim koristima od turizma za zajednice u kojima obitava. Također, istraživanja ukazuju na društvene koristi obitavanja vuka kroz doprinos zdravlju, socijalnoj koheziji u lokalnim zajednicama i sl. Ovi nalazi korisna su osnova za planiranje upravljanja populacijom vuka u lokalnim zajednicama. $\mathrm{Uz}$ vrednovanje socioloških i ekonomskih učinaka vuka javljaju se novine koje su u vezi s recentnim istraživanjima kulturnih učinaka. Teme koje se istražuju odnose se na nematerijalne vrijednosti poput kulturne raznolikosti i nematerijalne kulturne baštine, duhovne i religijske vrijednosti, obrazovne vrijednosti, estetske vrijednosti i društvene odnose.

Tijekom 2019. u Hrvatskoj su, u područjima Gorskog kotara, Like i Dalmacije, provedena prva istraživanja o stavovima stanovništva u vezi $s$ kulturnim učincima vuka u društvu i zajednici u kojoj obitava, a koji utječu na kreiranje nove perspektive i povezanosti s prirodom te na društvene veze. Rezultati istraživanja ukazuju na niz pozitivnih društvenih i kulturnih učinaka obitavanja vuka u lokalnim zajednicama, a koji umanjuju ekonomske štete koje nanose.

Uz pozitivne učinke na očuvanje biološke raznolikosti te ulogu u hranidbenom lancu, vuk je bitan dio kulturne baštine na područjima Like, Gorskog kotara i Dalmacije. Lokalno stanovništvo sve je više svjesno ovih učinaka i sve je tolerantnije prema vukovima. Stav prema vukovima uvelike se promijenio unatrag dvadesetak godina. Stanovnici područja u kojima vuk obitava smatraju kako vukovi imaju jednaka prava kao i ljudi te da bi trebali i dalje živjeti na teritoriju Republike Hrvatske. 
Ipak, u Hrvatskoj nije u potpunosti iskorišten sav potencijal vuka, posebno u turističkom i marketinškom smislu. Aktivnosti na očuvanju populacije vuka u Europi prilika su za razvoj i jačanje prekogranične suradnje, razmjenu znanja i iskustava te dobrih praksi u upravljanju vukom. Dugoročne pozitivne socioekonomske i kulturne učinke moguće je ostvariti kroz dodatne edukacije o vrijednosti i važnosti prisutnosti vuka u lokalnim zajednicama, intenziviranje međusektorskog pristupa u istraživanjima te komunikaciji među stručnjacima, razmjeni podataka, iskustava i primjera dobrih praksi na globalnoj razini. Pritom je baština u obliku priča, legendi i narodnih običaja nezaobilazan dio identiteta lokalnih zajednica u kojima vuk obitava. Stoga očuvanje ovih tekovina i sadržaja predstavlja zajedničku aktivnost društva u cjelini.

\section{LITERATURA}

Ambarly, H. i Bilgin, C. (2008). Human-Brown Bear Conflicts in Artvin, Northeastern Turkey: Encounters, Damage, and Attitudes. Ursus, 19(2): 146-153.

Balčiauskas, L. i Kazlauskas, M. (2012). Acceptance of brown bears in Lithuania, a non-bear country. Ursus, 23(2): 168-178.

Blanco, J. (ur.) (2012). Towards a population level approach for the management of large carnivores in Europe: Challenges and opportunities. A Istituto di Ecologia Applicata and IUCN/SSC Large Carnivore Initiative for Europe report prepared for the European Commission, No. No070307/2012/629085/SER/B3.

Boitani, L. (2000). Action Plan for the conservation of the wolves (Canis lupus) in Europe. Nature and Environment Series, No. 113. Strasbourg: Council of Europe Publishing.

Boitani, L. i Linnell, J. D. C. (2015). Bringing Large Mammals Back: Large Carnivores in Europe. U: Navarro, L. i Pereira, H. (ur.), Rewilding European Landscapes (str. 67-84). New York: Springer Open.

Cerqueira, Y., Navarro, L., Maes, J., Marta-Pedroso, C., Honrado, J. i Pereira, H. (2015). Ecosystem Services: The Opportunities. U: Navarro, L. i Pereira, H. (ur.), Rewilding European Landscapes (str. 47-64). New York: Springer Open.

Dragić, M. (2010). Duhovna baština Hrvata u šibenskom zaleđu. Godišnjak Titius: godišnjak za interdisciplinarna istraživanja porječja Krke, 3(3): 123-174.

Echegaray, J. i Vila, C. (2010). Noninvasive monitoring of wolves at the edge of their distribution and the cost of their conservation. Animal Conservation, 13(2): 157161.

Ericsson, G. i Heberlein, T. (2003). Attitudes of hunters, locals, and the general public in Sweden now that the wolves are back. Biological Conservation, 111(2): 149-159.

Fernandez-Gil, A., Naves, J., Ordiz, A., Quevedo, M., Revilla, E. i Delibes, M. (2016). Conflicts Misleads Large Carnivore Management and Conservation. Brown Bears and Wolves in Spain. PLOS ONE, 11(3): 1-13. DOI: 10.1371/journal. pone. 0151541 . 
Højberg, P., Nielsen, M. i Jacobsen, J. (2017). Fear, economic consequences, hunting competition, and distrust of authorities determine preferences for illegal lethal actions against gray wolves (Canis lupus): a choice experiment among landowners in Jutland. Crime Law and Social Change, 67(4): 461-480.

Huber, Đ., Radišić, B., Novosel, D. i Frković, A. (1994). Istraživanja javnog mnijenja o vukovima u Hrvatskoj. Šumarski list, 118(5-6): 167-172.

Jeremić, J. i Štrbenac, A. (ur.) (2014). Izvješće o stanju populacije vuka u Hrvatskoj u 2014. godini. Zagreb: Državni zavod za zaštitu prirode.

Jeremić, J. i Štrbenac, A. (ur.) (2015). Izvješće o stanju populacije vuka u Hrvatskoj u 2015. godini. Zagreb: Hrvatska agencija za okoliš i prirodu.

Klinkhart, M., Gigler D. i Patkó, L. (2018). Farkas nélkül nincs mese? Értékes ordas. A Földgömb magazin, 36(11): 32-41.

Lescureux, N. i Linnell, J. (2013). The effect of rapid social changes during post-communist transition on perceptions of the human - wolf relationships in Macedonia and Kyrgyzstan. Pastoralism: Research, Policy and Practice, 3(4): 1-20. DOI: 10.1186/2041- 7136-3-4.

Linnell, J. D. C. (2013). From conflict to coexistence: insights from multi-disciplinary research into the relationships between people, large carnivores and institutions. A Istituto di Ecologia Applicata, Norwegian Institute for Nature Research and IUCN/SSC Large Carnivore Initiative for Europe report prepared for the European Commission, No. 070307/2012/629085/SER/B3.

Linnell, J. D. C. i Cretois, B. (2018). Research for AGRI Committee - The revival of wolves and other large predators and its impact on farmers and their livelihood in rural regions of Europe. Bruxelles: European Parliament, Policy Department for Structural and Cohesion Policies.

Linnell, J. D. C., Salvatori, V. i Boitani, L. (2018). Guidelines for Population Level Management Plans for Large Carnivores. A Large Carnivore Initiative for Europe report prepared for the European Commission, No. 070501/2005/424162/MAR/B2.

Majić, A. i Bath, A. (2009). Changes in attitudes toward wolves in Croatia. Biological Conservation, 143(1): 255-260.

Milheiras, S. i Hodge, I. (2011). Attitudes towards compensation for wolf damage to livestock in Viana do Castelo, North of Portugal. Innovation - The European Journal of Social Science Research, 24(3): 333-351.

Navarro, L. i Pereira, H. (2015). Rewilding Abandoned Landscapes in Europe. U: Navarro, L. i Pereira, H. (ur.), Rewilding European Landscapes (str. 3-24). New York: Springer Open.

Nilsen, E., Milner-Gullard, E., Schofield, L., Mystreud, A., Stenseth, N. i Coulson, T. (2007). Wolf reintroduction to Scotland: Public attitudes and consequences for red deer management. Proceedings of the Royal Society B: Biological Sciences, 274(1612): 995- 1003.

Palazón, S. (2017). The Importance of Reintroducing Large Carnivores: The Brown Bear in the Pyrenees. U: Catala, J., Ninot, J. i Mercè Aniz, M. (ur.), High Mountain Conservation in a Changing World (str. 231-249). Cham: Springer Open. 
Ripple, W. i Beschta, R. (2004). Wolves and the ecology of fear: can predation risk structure ecosystems? BioScience, 54(8): 755-766.

Rode, J., Karutz, R., Berghöfer, A., Schröter-Schlaack, C. i Flinzberger, L. (2019). Assessing the Socio-Economic Impacts of Large Carnivores in Europe. Guidance document and templates. Leipzig: Faktor Natur Consulting.

Røskaft, E., Händel, B., Bjerke, T. i Kaltenborn, B. (2007). Human attitudes towards large carnivores in Norway. Wildlife Biology, 13(2): 172-185.

Sillero-Zubiri, C. i Laurenson, K. (2001). Interactions between carnivores and local communities: Conflict or co-existence? U: Gittleman, J., Funk, S., Macdonald, D. W. i Wayne, R. K. (ur.), Proceedings of a Carnivore Conservation Symposia (str. 282312). London: Zoological Society of London.

Widman, M. i Elofsson, K. (2018). Costs of Livestock Depredation by Large Carnivores in Sweden 2001 to 2013. Ecological Economics, 143:1 88-198. 


\title{
WHO'S AFRAID OF THE BIG BAD WOLF? SOCIO-ECONOMIC AND CULTURAL EFFECTS OF THE WOLF HABITATS IN CROATIA
}

\author{
Sanja Tišma, Daniela Angelina Jelinčić, Iva Tolić, Andrea Solić and Snježana Malić Limari
}

\begin{abstract}
The conservation of wolves in modern European landscapes has proven to be very challenging due to several different problems related to their presence and controversies about how they are managed. The Republic of Croatia is one of the few wolf-dwelling areas in Europe today.

This article presents the analysis of recent scientific papers on the socio-economic and cultural effects of wolves on local communities. In addition to the analysis of relevant scientific research, the article presents the results from the first research on the socio-economic and cultural impact of wolves in Croatia. The research was conducted in the period between July and October 2019 in local communities in which wolves are traditionally present. The main hypothesis was that the higher quality of information about the wolf population will lead to improved monitoring, management, and acceptance of wolves in the local communities. The results indicate the need for better education, stronger cross-sectoral cross-border cooperation to increase the understanding of the wolf population and their impact on sustainable local development, and the need for the joint conservation of natural and cultural heritage.
\end{abstract}

Keywords: wolf habitat, socio-economic effects, cultural effects, local community, tourism, branding

\section{WER HAT ANGST VOR DEM BÖSEN WOLF? SOZIALÖKONOMISCHE UND KULTURELLE AUSWIRKUNG DER ANSIEDLUNG DER WÖLFE IN KROATIEN}

Sanja Tišma, Daniela Angelina Jelinčić, Iva Tolić, Andrea Solić und Snježana Malić Limari

\section{Zusammenfassung}

Die Erhaltung der Wölfe hat sich in modernen europäischen Landschaften als sehr anspruchsvoll gezeigt, weil es hinsichtlich deren Anwesenheit viele Herausforderungen und Kontroversien wegen der Art und Weise gibt, wie man mit ihnen umgehen sollte. Republik Kroatien ist eines der seltenen Gegende in Europa, wo Wölfe noch angesiedelt sind.

In diesem Artikel wird die Analyse der rezenten wissenschaftlichen Forschung der sozialökonomischen und kulturellen Auswirkungen der Wölfe auf die lokalen Gemeinschaften dargestellt, wo die Wölfe angesiedelt sind. Neben der Analyse der relevanten wissenschaftzlichen Forschung der Wölfe bringt der Artikel auch die Ergebnisse der ersten Forschung der sozialökonomischen und kulturellen Auswirkungen der Wölfe in Kroatien. Die Forschung wurde im Zeitraum vom Juli bis Oktober 2019 in lokalen Gemeinschaften durchgeführt, wo Wölfe traditionell anwesend sind. Die Hypothese der Forschung ist, dass relevante Informationen über die Population der Wölfe mehr Möglichkeiten für deren Akzeptanz, Beobachten und Verwalten in lokalen Gemeinschaften bieten. Die Forschungsergebnisse weisen auf die Notwendigkeit einer zusätzlichen Eduzierung und einer stärkeren Zusammenarbeit unter den Staaten und Sektoren hin, um die Dynamik der Wölfepopulation und deren Einfluß auf die nachhaltige lokale Entwicklung und Erhaltung des Naturund Kulturerbes besser zu verstehen.

Schlüsselwörter: Ansiedlung der Wölfe, sozialökonomische Auswirkungen, kulturelle Auswirkungen, lokale Einwohner, Tourismus, Branding 